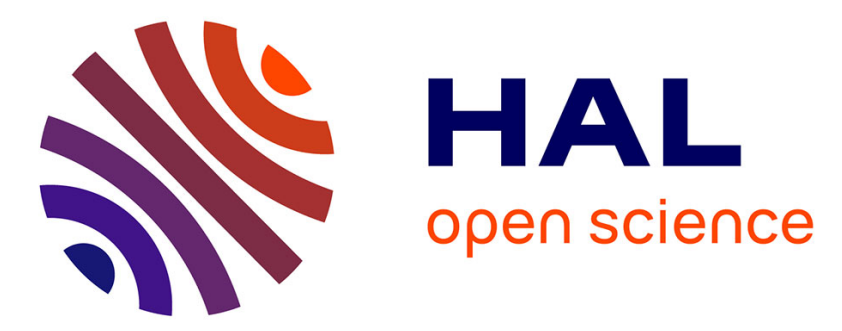

\title{
Lessons learned from 25 years of PMIP model-data distribution
}

Jean-Yves Peterschmitt, Pascale Braconnot, Masa Kageyama

\section{To cite this version:}

Jean-Yves Peterschmitt, Pascale Braconnot, Masa Kageyama. Lessons learned from 25 years of PMIP model-data distribution. Past Global Changes Magazine, 2018, 26 (2), pp.60-61. 10.22498/pages.26.2.60 . hal-03260013

\section{HAL Id: hal-03260013 https://hal.science/hal-03260013}

Submitted on 14 Jun 2021

HAL is a multi-disciplinary open access archive for the deposit and dissemination of scientific research documents, whether they are published or not. The documents may come from teaching and research institutions in France or abroad, or from public or private research centers.
L'archive ouverte pluridisciplinaire HAL, est destinée au dépôt et à la diffusion de documents scientifiques de niveau recherche, publiés ou non, émanant des établissements d'enseignement et de recherche français ou étrangers, des laboratoires publics ou privés. 


\title{
Lessons learned from 25 years of PMIP model-data distribution
}

\author{
Jean-Yves Peterschmitt, P. Braconnot and M. Kageyama
}

\section{Open paleo data from both observations and models underlies the success of the Paleoclimate Modelling Intercomparison Project. We present how the project has evolved from a stand-alone database to an active member of a distributed international infrastructure following community standards.}

Climate models are improved iteratively, as scientific knowledge, along with computing and storage technology progress. Sharing and comparing models and their output to paleo reconstructions is an essential part of this process. This can be done by sharing data directly between individuals, but is more efficient when formally organized as a MIP (Model Intercomparison Project), where all contributors and users adopt the same standards. The Paleoclimate Modelling Intercomparison Project (PMIP), started in 1990 (Joussaume and Taylor 1995), was one of the early MIPs, following the AMIP example (Gates et al. 1998).

PMIP has been successful in terms of participation, publications, and contributions to successive IPCC Working Group 1 reports, and is now in its fourth phase, with 20 modeling groups/models from 14 countries (Kageyama et al. 2018; Kageyama et al. 2016 [PMIP4 special issue]). The first studied periods were the mid-Holocene and the Last Glacial Maximum, with the pre-industrial period used as a control run. PMIP4 now includes five additional experiments: the last millennium, the Last Interglacial, the mid-Pliocene Warm Period, the last deglaciation and DeepMIP. Thanks to improvements in model complexity, resolution, and length of the simulations, the different phases of PMIP have targeted key scientific questions on climate sensitivity, the hydrological cycle, and abrupt event and inter-annual to multidecadal variability

For PMIP4, experimental protocols were co-designed by the modeling and data communities (Kageyama et al. 2018). They require that the same model version be used for PMIP4-CMIP6 experiments and future climate projections so that rigorous analyses of climate processes, including both physical and biogeochemical interactions, can be performed across the range of past and future climate. This is done in collaboration with other CMIP6 MIPs (Eyring et al. 2016).

PMIP simulations address the key CMIP6 overarching questions:

- How does the Earth system respond to forcing?

- What are the origins and consequences of systematic model biases?

- How can we assess future climate changes given climate variability, predictability and uncertainties in scenarios?

\begin{tabular}{|c|c|c|c|c|}
\hline & PMIP 1 & PMIP 2 & PMIP 3 & PMIP 4 \\
\hline DB online & 1996 & 2005 & 2011 & 2018 \\
\hline $\begin{array}{l}\text { Number of groups/ } \\
\text { models }\end{array}$ & 22 & 18 & 25 & 20 \\
\hline $\begin{array}{l}\text { Number of } \\
\text { countries }\end{array}$ & 11 & 10 & 12 & 14 \\
\hline Main experiments & $\begin{array}{c}0 k \\
6 k \\
21 k\end{array}$ & Same as PMIP 1 & $\begin{array}{c}\text { PMIP } 2 \\
\text { + Last } \\
\text { Millennium }\end{array}$ & $\begin{array}{c}\text { PMIP3 } \\
+ \text { Last Interglacial } \\
+ \text { Mid Pliocene Warm Period } \\
+ \text { Last Deglaciation } \\
\text { + DeepMIP }\end{array}$ \\
\hline DB Size & $1.7 \mathrm{~GB}$ & $482 \mathrm{~GB}$ & $\begin{array}{l}\text { distributed } \\
\text { several TB }\end{array}$ & $\begin{array}{l}\text { distributed } \\
\text { LOTS of TB... }\end{array}$ \\
\hline Data distribution & $\begin{array}{c}\text { ftp server } \\
\text { LSCE (+PCMDI) }\end{array}$ & $\begin{array}{c}\text { DODS server } \\
\text { LSCE }\end{array}$ & $\begin{array}{l}\text { CMIP5 } \\
\text { ESGF }\end{array}$ & $\begin{array}{l}\text { CMIP6 } \\
\text { ESGF }\end{array}$ \\
\hline $\begin{array}{l}\text { Data format \& } \\
\text { Convention }\end{array}$ & $\begin{array}{l}\text { NetCDF } \\
\text { AMIP/CF }\end{array}$ & $\begin{array}{c}\text { NetCDF } \\
\text { CMIP+PMIP2/CF }\end{array}$ & $\begin{array}{l}\text { NetDCF } \\
\text { CMIP5/CF }\end{array}$ & $\begin{array}{l}\text { NetCDF } \\
\text { CMIP6/CF }\end{array}$ \\
\hline $\begin{array}{l}\text { Example grid IPSL } \\
\text { atmosphere }\end{array}$ & $\begin{array}{l}\text { Imcelmd5 } \\
64 \times 50 \times \text { L11 }\end{array}$ & $\begin{array}{l}\text { IPSL-CM4-V1-MR } \\
96 \times 72 \times \text { L19 }\end{array}$ & $\begin{array}{l}\text { IPSL-CM5A-LR } \\
96 \times 95 \times \text { ×39 }\end{array}$ & $\begin{array}{c}\text { IPSL-CM6A-LR } \\
144 \times 143 \times \text { L79 }\end{array}$ \\
\hline $\begin{array}{l}\text { Example grid } \\
\text { NCAR atmosphere }\end{array}$ & $\begin{array}{c}\text { Ccsm3 } \\
128 \times 64 \times \text { L18 }\end{array}$ & $\begin{array}{c}\text { CCSM } \\
128 \times 64 \times \text { L17 }\end{array}$ & $\begin{array}{c}\text { CCSM4 } \\
288 \times 192 \times \text { L26 }\end{array}$ & $\begin{array}{c}\text { CESM2 } \\
288 \times 192 \times \text { L32 }\end{array}$ \\
\hline
\end{tabular}

Current work places a particular emphasis on the assessment of the different sources of uncertainties resulting from, for example, model formulation, reconstructions of forcing, and internal model noise. Modeldata comparisons are key in this process (Braconnot et al. 2012; Harrison et al. 2015)

The PMIP model database has progressed from almost 2 GB for PMIP1 ( 14,500 files) to a frightening (and unknown!) number of terabytes for PMIP4 (Box 1). Standards and good data-distribution tools are the key to dealing with the massive amount of data generated, along with good communication tools (mailing lists and websites), and invaluable help from the Earth System Grid Federation (ESGF; Balaji et al. 2018) community that maintains the CMIP database.

\section{Using standards}

The database of model output is too large to be accessed by ordinary database queries. Nevertheless, users need to easily access the subset of the data they need for their analyses, regardless of which research group generated it. In PMIP, this is achieved through the use of community standards. Standards are sometimes viewed as a hindrance to data production, but they are necessary to avoid chaos when working with multi-model data the essence of a MIP. Data that is consistent across all the models and experiments eases reuse by users, and is required to automatically process numerous files, easily ingest new files, and to reprocess files when a bug is found. Such standardization also generally makes any analyses more reproducible.

Standardization is a key aspect of the long history of PMIP in international collaborations. PMIP currently follows the CMIP6 standards for file format (NetCDF format) and metadata (Climate and Forecast conventions, CMIP6 Data Reference Syntax, Controlled Vocabulary and Data Request). The NetCDF binary format has many advantages: self-describing, easily and efficiently writable/readable by programs, capacity to hold several gigabytes of data, and suitable for long-term archiving. Thanks to these choices it is still possible to access the content of PMIP1 files created more than 20 years ago. It is not easy for the modeling groups to meet the CMIP6 requirements, but the Climate Model Output Rewriter (CMOR3) library and project-specific configuration 
In [1]: import cdms2, cdutil, vcs

In [2]: $f=$ cdms2.open('/home/scratch01/jypeter/tas_IPSL-CM5A-LR_21-0.nc')

In [3]: $v=f\left(' t a s \_d i f f '\right)$

In [4]: v_annual_mean $=$ cdutil.YEAR(v)

In [12]: $x=$ vcs.init(geometry $=(600,400), b g=$ True)

In [16]: x.plot(v_annual_mean)

Out [16]:

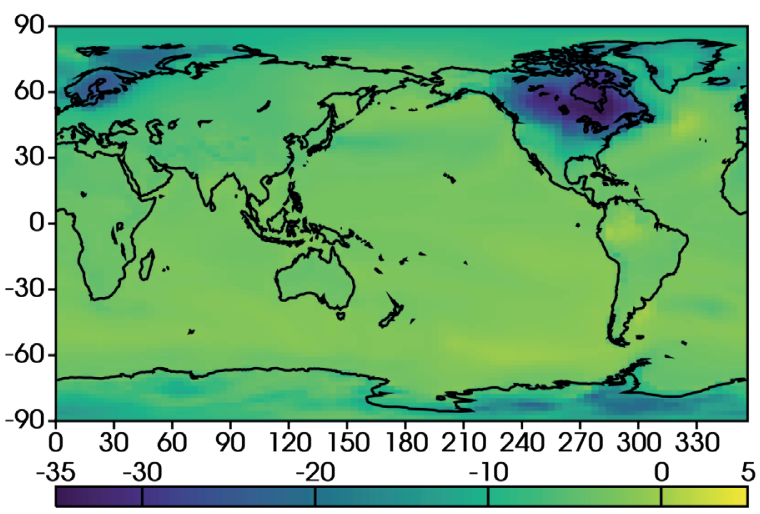

In [17]: x.clear()

x.plot( $($ _annual_mean(latitude $=(20,80)$, longitude $=(-20,40))$, ratio='autot')

Out [17]:

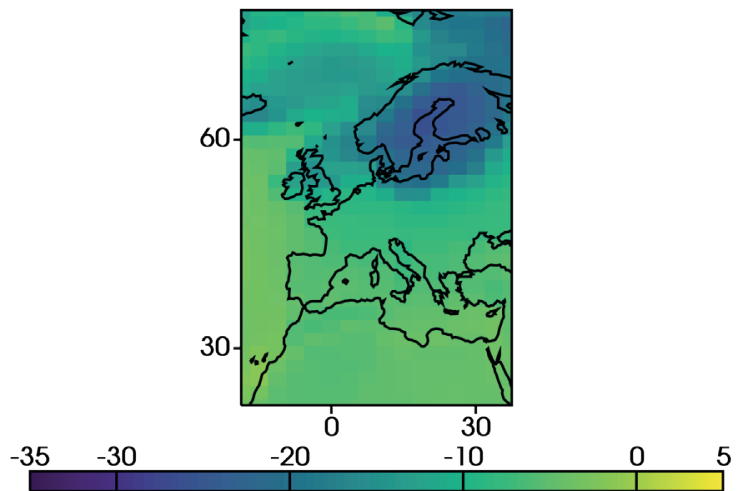

Figure 1: An example of a script using the CDAT climate-oriented Python distribution in a notebook to read PMIP3 data from a NetCDF file (surface temperature, anomaly for the Last Glacial Maximum minus the preindustrial control, for the IPSL-CM5A-LR model), compute the annual mean and plot it on a global grid and a smaller region.

tables facilitate the creation of CMIPcompliant files.

\section{Accessing model data}

Once the data files are available in the standard format, the next goal is to ensure they move as smoothly as possible from the data provider to the data user. This is accomplished through a number of developments:

- Model-output data providers need an automatic service to answer user requests.

- Users want to determine easily if the required data is available, and then to easily access the files. Given the size of the database (Box 1) there are ongoing developments to provide computation and analysis services directly on the servers holding the data.

- Users need a good documentation of the models and how the PMIP experiments were run. For PMIP4-CMIP6, this information will be centralized on the Earth System Documentation (es-doc) site.

For CMIP5-6 (PMIP3-4), the data files are sent by the modeling groups to the closest ESGF Data Node and, after review ranging from a basic validation to an exhaustive quality control, they can be searched and downloaded from any other node of the federation. This distributed repository is scalable and is the only practical way to handle the 10-50 petabytes of data expected for CMIP6 (including PMIP4 data). ESGF also offers a fast web-search interface and bulk datadownload tools. This infrastructure is powerful, but it requires substantial manpower for customized software development and local node administration, as well as sufficient storage and computing resources.

In addition to standardization, the PMIP data policy has evolved over time. For PMIP1, the full database was initially available only for the groups which had submitted data during an embargo period, prior to public release. For PMIP2, the database was also available for people proposing an analysis project. PMIP3-4 followed the CMIP5-6 data policy, which allows anyone to use the data from modeling groups, with some restrictions for commercial applications. In turn, the results of the study that uses the model output must be shared with the same open policy, without forgetting to credit the producers.

\section{Using PMIP data}

There are many ways to use PMIP model data, depending on the analyses to be done. The data complexity (number of available variables and file size) has increased substantially since the beginning of PMIP, but the programing complexity has decreased. It is now much easier to use a high-level scripting language (Fig. 1) than it was to use Fortran programs. Users can also process PMIP data with the Graphical User Interfaces provided by some programs (e.g. GIS programs such as QGIS), but they may be quickly limited by data size and available operations. There is also an ongoing effort by the PMIP community to provide some higher-level web interface; this will receive more attention in the coming years.

\section{Conclusion}

PMIP has benefited from CMIP5- 6 and the ESGF infrastructure, which has eased the comparison between past and future climate simulations. One of the next challenges is to make using the data easier for nonmodelers, especially experts in paleoclimate reconstructions. This will require the deployment of specific web servers similar to the ones used for impact studies, but customized for paleoclimate needs. Another challenge will be to deal with the long, transient climate simulations (thousands of years of model data) generated by the PMIP4 experiments (deglaciation, the Eemian and the Holocene) when performing model-model and model-data comparisons.

\section{RESOURCES}

PMIP: pmip.Isce.ipsl.fr

AMIP and CMIPn: pcmdi.llnl.gov/mips

PMIP3 publications: citeulike.org/user/jypeter/order/ year

NetCDF: unidata.ucar.edu/software/netcdf

CF conventions: cfconventions.org

CMIP6 DRS: goo.gl/v1drZl

CMIP6 DR: earthsystemcog.org/projects/wip/

CMIP6DataRequest

CMIP6 CV: github.com/WCRP-CMIP/CMIP6_CVs

CMOR3 library: cmor.llnl.gov

es-doc: search.es-doc.org

CDAT: cdat.IInl.gov

QGIS: qgis.org

DeepMIP: deepmip.org

\section{AFFILIATIONS}

Laboratoire des Sciences du Climat et de

I'Environnement (LSCE/IPSL, CEA-CNRS-UVSO),

Université Paris-Saclay, Gif-sur-Yvette, France

\section{CONTACT}

Jean-Yves Peterschmitt: Jean-Yves.Peterschmitt@lsce. ipsl.fr

\section{REFERENCES}

Balaji V et al. (2018) Geosci Mod Dev 11: 3659-3680 Braconnot P et al. (2012) Nat Clim Change 2: 417-424 Eyring V et al. (2016) Geosci Mod Dev 9: 1937-1958 Gates WL et al. (1998) BAMS 73: 1962-1970 Harrisson SP et al. (2015) Nat Clim Change 5: 735-743 Joussaume J, Taylor K (1995) Proceedings of the first international AMIP scientific conference, Monterey, USA: $425-430$

Kageyama M et al. (2016) CP/GMD inter-journal SI Kageyama M et al. (2018) Geosci Mod Dev 11: 1033-1057 